\title{
Exploring the Relationship of Customer Loyalty with Customer Value based on Trust, Customer Satisfaction and Switching Costs in a B2B Market
}

\author{
Donia Waseem ${ }^{1}$ \\ Dr. M. Zaki Rashidi²
}

\begin{abstract}
Customer loyalty significantly impacts upon the success of business organization and it is considered an important source of competitive asset. Earlier, researchers have studied the relationship of customer loyalty, both patronage and recommend, with switching cost, customer satisfaction, customer value constructs in the context of business to consumer (B2C). This research study extends the previous research studies by relating these constructs in a business to business $(B 2 B)$ environment. It aims to empirically test the relationship among these constructs and develops a framework for a $B 2 B$ environment. The research methodology is quantitative in nature whereas convenience sampling method is adopted from a target population. A questionnaire is developed by using 31 items on a five-point Likert scale. Total 350 questionnaires are distributed during only 92 valid questionnaires are received thus the response rate is observed as $26.28 \%$. The results of the research study show that the five independent variables (customer satisfaction, customer value, switching costs, trust and prices) are significantly correlated with each other. Therefore, B2B marketing professionals should devise their marketing strategies accordingly.
\end{abstract}

Keywords: B2B market, customer loyalty, customer value, customer satisfaction, service quality, switching costs

\section{Introduction}

Customer loyalty not only is a source of competitive asset but also strongly ompacts upon the success of business organizations because retaining old customers is less expensive than attracting new customers. Reichheld (1993) proved that the outcomes are increased revenue with lower cost of customer acquisition and repeat purchases. According to Kotler (1997), customer loyalty is the key factor in the market strategic planning. Strong vendor and buyer relationship enhances the association (Doney \& Cannon, 1997); and relationship of loyal buyers in an organization engages in a long-term mutual benefit which focuses on enhancing the competitiveness and reduces the transactional costs (Reichardt 1993). In practice, companies strive to build a long term relationship with their customers and try to retain them to gain their competitive advantage, which results in reduced revenue base and consistent revenue. Although the research on customer loyalty in the business to business (B2B) perspective is limited but its impact in business to consumer (B2C) context is widespread; as the B2B context is completely different from the $\mathrm{B} 2 \mathrm{C}$ context, therefore its implications are also different (Li, 2012).

Zimmerman and Blythe (2013) proposed that in non-consumer markets, buying decisions are more rationale. The buying scenario in a B2B market is very different, the buyer is a refined purchaser who is involved with different vendors for the same product and various

\footnotetext{
${ }^{1}$ Donia Waseem is Deputy Manager, Product \& Marketing, Shabbir Tiles \& Ceramics Ltd., donya_waseem@hotmail.com ${ }^{2}$ Dr. M. Zaki Rashidi is Assistant Professor, Management Science, SZABIST, Karachi, zaki@szabist.edu.pk

\begin{tabular}{llll|l}
\hline JISR-MSSE & Volume 11 & Number 2 & July - December 2013 & 39
\end{tabular}
}


departments are involved in the buying process. The buyer in such a scenario does not involve in impulse buying and hence the process is considered as more refined but complicated. The traditional concepts of customer's value, loyalty, satisfaction, and trust, along with switching cost are constantly challenged in this context. Stated alternatively, a business is considered as enterprising, a characterization that captures the activities of those with whom they exchange, than is implied by 'consumer' which has rather passive, final connotations of a 'target' with a primary activity of using stuff up, rather than creating and contributing.

In the B2C context, previous researchers have studied the relationships of customer loyalty with service quality, customer satisfaction, price and trust. This study aims to explore the linkage of conceptual framework of the constructs in B2B context. The study aims to first explore a framework based on the customer's trust, loyalty, satisfaction, perceived value and switching costs in a B2B context. It further empirically tests the developed framework in a B2B environment. It has two major objectives: first, to analyze a framework in a B2B context of customer loyalty based on trust, customer perceived value, customer satisfaction and switching costs; and the second, to empirically analyze the developed conceptual framework of customer loyalty in a B2B environment on the basis of customer's antecedents that includes satisfaction, trust, perceived value and switching costs.

This research study explores the mutual effect of customer loyalty (patronage and recommend) with customer's satisfaction, switching costs, value and loyalty in a B2B environment in comparison to previous empirical research which analyzes these relationships in a B2C context. The study aims to provide valuable insights to facilitate B2B marketers to consider these linkages while formulating strategies considering the interrelationships between constructs such as customer's loyalty value, switching costs and satisfaction. The business markets are far bigger and profitable as compared to the consumer markets and hence understanding the professional buyers as compared to the consumers are significant to develop the overall marketing strategies. The research aims to aid b2b marketing professionals for strategic direction setting. It aids the marketers to identify the key potential areas in business. It will also uncover and identify the problems that occur and aid to formulate targeted marketing campaigns.

\section{Literature Review}

Customer loyalty is defined as a customers' repeated or continuous purchase behavior towards the product or service of a specific company (Day, 1977; Lutz (1986). Buyer's profound attachment to a product, brand, service or organization is referred as customer loyalty (Oliver, 1999). However, Bhote (1996) suggested that the customer satisfaction results in customer loyalty and this leads to promoting the company through positive word-of-mouth. Customer behavior, intention to repurchase a product or service and recommending a product through word of mouth must be classified through intention to repeat purchase, primary and secondary behavior (Parsuraman et al., 1994). Two methods to measure to measure the loyalty are well known as customer retention and advocacy. Dick and Basu (1994) and Oliver (1999) propose that loyalty is conceptualized by various approaches, which are based on behavioral conceptualizations, attitudinal conceptualizations and both attitudinal and behavioral conceptualizations. Behavioral conceptualization view suggests that the term customer loyalty is revealed by behavior such as repeat purchase, purchase cycle and market share. The Attitudinal conceptualization suggests that customer loyalty is revealed by attitude such as 
whether the people like the brand, suggest it to others, feel committed to it and have positive beliefs while comparing it with other brands. The combined behavioral and attitudinal conceptualization considers both the behavioral and attitudinal contexts cited above. The quality of a relationship between the customer and seller decreases the uncertainty of buyer and strengthens the firm and customer relationship (Caceres \& Paparoidamis, 2007).

The existence of customer value are investigated through two perspectives i.e. the companys' view and the customers' view. The main objective from the company's viewpoint is to measure the life time value (customer equity) of an individual customer or customer groups. As perceived by the customer, the focus is on the produced value by a service or a product. Lemon et al (2001) have posited that customer value is derived from three key factors such as convenience, price and quality. Customer value as described by Gale (1994) is the relative price of the product adjusted for the market perceived quality. It is an opinion of a product or service by a customer's as compared to the competitor. Zeithaml (1988) has described the perception of what is given and what is received compared to the overall evaluation of the value of a service or a product as the perceived value. The definition of customer value as suggested by Woodruff (1997) is "customer's perceived preference for and evaluation of those products attributes, attribute performance, and consequences arising from use that facilitate (or block) achieving the customer's goals and purposes in use situations" (p.141). The research studied show that perceived value has either direct impact on trust (Kim, Zhao \& Yang, 2008) or has an indirect impact on the perceived value through the intervention of customer satisfaction (Moliner et al., 2007). Matthew and Christine (2000) have proposed that the customer's emotional and rational perceptions based on service experience are known as customer satisfaction. Kotler \& Keller (2006) have further added in that a customer satisfaction is a person's disappointment or approval while comparing their opinion of services received with their expectation of original services.

The customer satisfaction is quite different in a B2B context as compared to B2C. In B2B context, customer satisfaction is defined as a company's working relationship with another company's positive affirmation which results from the evaluation of all aspects (Geyskens, Steenkamp \& Kumar, 1999). Zeithaml and Bitner (1996) have discussed that previous research studies had identified five aspects of determining customer satisfaction as: product, service, price, situation, and individual. $\mathrm{Li}$ (2012) has proposed that two factors accredit the shortcoming of customer satisfaction; namely, non-fulfillment of customers need and wants, and lack of trust and commitment. From the existing vendor to a new supplier switching cost refers costs of switching as perceived by the buyer (Liao, 2012). In fact the cost does not only include the cost of switching at the actual moment, but it also refers to the psychological cost of searching for new information, special privileges, accessing information, performing the actual transaction, the cognitive efforts, and the special privileges (Fornell, 1992). These costs are only highlighted when the customer is poised to the situation of switching. Jones, Mothersbaugh and Beatty (2002) have developed a multi-dimensional scale in a B2C context; however, limited research studies exist for elaborating the various types of switching costs in B2B relationship marketing (Burnham, Frels \& Mahajan, 2003).

The trust with respect to customer loyalty has great significance on business performance (Lim \& Razzaque, 1997); it is taken as the positive intentions of one party towards the other with respect to the relationship of assurance or acknowledgement (Callaghan, McPhail \& Yau, 1995); and as confiding in partner honesty and reliability (Morgan \& Hunt, 1994). 
Customers trust helps to develop long term relationship and encourages in better understand the needs of the customers that benefit the companies (Czepiel, 1990). Trust and closeness in interpersonal relationships improve the quality of the relationship (Wong \& Sohal, 2002); while it reduces the customer risk and improves the relationship for mutual long term benefit. Many researchers (e.g. Boersma, Buckley \& Ghauri, 2003; Kemp \& Ghauri, 1998; Morgan $\&$ Hunt, 1994) have reported that the customer's value and satisfaction are two different concepts; where customer value is seen as an antecedent of customer satisfaction but the rationale behind this relationship varies. Customer value is considered as a cognition-based construct whereas customer satisfaction refers to an effective and evaluated reaction (Oliver, 1993). Also the cognitive thoughts cause affective responses (Weiner, 1986). This gives rise to the view that the satisfaction perception is affected by the customer value judgment.

Customer satisfaction is considered as an affective-cognitive construct while customer value as a cognitive construct. Fishbein and Ajzen (1975) have suggested that affective variables mediate the cognitive variables which result in cognitive outcomes. However, not many research studies have been conducted on the reciprocal relationship (Vakratsas \& Ambler, 1999). Many researchers (e.g. Ganesan, 1994; Mittal \& Kamakura, 2001; Mittal, Ross, \& Baldasare, 1998) have shown that customer satisfaction affects positively customer loyalty, and customers who are satisfied with the products or services of a company motivate, patronize and recommend it to other customers (Lam et al., 2009), which leads the researchers to conclude that the customer satisfaction is affected positively by both the dimensions of loyalty. Although the repeat patronage and customer satisfaction relationship may be considered as a non-linear relationship, but Heskett et al. (1997) have suggested that as soon as the customer satisfaction exceeds a certain level of threshold it increased the customer loyalty. They have further elaborated that the returns to the relationship between customer satisfaction and loyalty are increasing (Lem et al., 2009).

Dwyer et al (1987) and Shankar et al (2003) have identified that from a repeated interaction between a buyer and a seller, loyal customers are likely to derive more personal and nonmonetary satisfaction as compared to disloyal customer; whereas Ahluwalia, Unnava \& Burnkrant (1999) have suggested that the disloyal customers are more prone to the negative information about a service than loyal customers. There are high chances that the two aforementioned constructs have reciprocal effect as customer loyalty drives customer satisfaction. This view is applicable for the patronage component of loyalty; whereas, there is no strong evidence which suggests that the same is relevant for the recommend component of the loyalty. The literature reveals that customer satisfaction is affected by customer value; and customer loyalty is affected by customer satisfaction (Bolton \& Drew, 1991). Customer satisfaction and value are positively related to the loyalty (Sirdeshmukh et al., 2002) and it plays the intervening role between customer loyalty and customer value (Cronin, Brady, \& Hult, 2000). Ajzen and Fishbein (1975) provided a theoretical framework of the mediating role in an attitudinal literature were the cognition leads to affect which further leads to the behavioral intent.

The cognition variable is the exchange of the benefits and costs of using a particular product or service and is also known as the customer value (Lam et al., 2009), customer satisfaction is therefore an affect variable. Loyalty is customers' repeated or continuous purchase behavior towards the product or service of a specific company. Customer loyalty stimulates positive behavior towards the service provider. The literature, therefore, suggests that customer's

\begin{tabular}{l|llll}
\hline 42 & July - December 2013 & Volume 11 & Number 2
\end{tabular} 
satisfaction mediates the effect of value on loyalty. Dwyer et al (1987) and Heide and Weiss (1995) reported that in order to reduce the switching costs, a customer would like to stay in an existing relationship considering every other aspect constant. The switching cost acts as barrier as building up a novel relationship represents investment of time, efforts and money; however, when the customer is dissatisfied then this relationship changes negatively. This acts as a barrier to moving to other vendor and supplier. It is also identified that loyalty benefits may be provided while ending the relationship as this may lead to a positive word of mouth and customer may recommend the product to others (Lam et al., 2009), which further affects the positive relationship between a recommend dimension of loyalty and switching cost. But, this relationship may also be related negatively in some circumstances, e.g. if a customer is dissatisfied and is not switching due to high switching costs then chances are that it will not recommend the company or product and it may also scandalize it.

\section{Conceptual Framework}

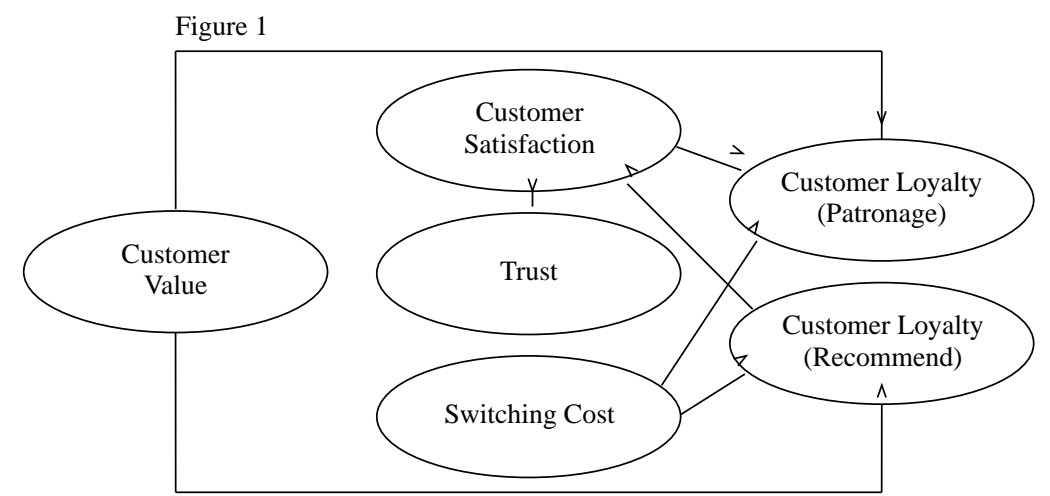

\subsection{Hypotheses}

H1: Customer value positively affects the customer satisfaction.

H2: The effect of customer's satisfaction on its loyalty (recommend and patronage) follows an increasing returns-to-scale relationship.

H3: Customer satisfaction positively affects the loyalty (recommend and patronage).

H4: Customer loyalty (patronage) effects the satisfaction positively.

H5: The relationship between customer value and loyalty (recommend and patronage) are mediated by its satisfaction either totally or partially.

H6: Switching costs have a positive effect on loyalty (patronage).

H7: Customer satisfaction affects the customer loyalty (recommendation) positively when switching costs are high in contrast to situation when switching costs are low.

H8: Trust positively relates to client loyalty.

\section{Research Methodology}

Post-positivist approach is adopted to conduct this research and empirical testing of hypotheses is done to achieve the research objectives. The research study provides a wider outlook whilst discovers credible solutions and seeks to find a dialogue on the theme. A survey based quantitative research methodology is adopted for this study. The data is collected from B2B 
marketing professionals. The target research participants were 32 female and 60 male urban B2B working marketing professional with their age range between 23 - 45 years. The research participants were working in the B2B Company at junior, middle, and upper management level. The size of the sample is moderate as the study concerns urban and literate marketing educated fragment of the society. Snowball sampling technique is used as the population was niche and difficult to develop a sampling frame due to unavailability constraints. An online survey is developed and conducted from B2B marketing professionals and around 400 questionnaires were targeted out of which only 92 valid filled questionnaires were obtained for further scrutiny with a measured response rate of approximately $25 \%$. Seven different constructs i.e. customer loyalty (patronage and recommend), customer satisfaction, switching costs, value, price, service quality, and trust as mentioned in conceptual framework, adapted from Lam et al (2009). Based on scale taken from previous research studies the questionnaire is developed with the measure of relevant constructs. To measure the content validity, a few modifications were made consistent with the specific features related to our research study by (Lam et al., 2009). The questionnaire consists of seven variables: service quality ( 7 items), price (5 items), customer satisfaction ( 5 items), switching cost (5 items), customer loyalty (recommend) (4 items) and customer loyalty (patronage) (2 items) and trust (5 items). Before deciding the scale measures, a senior professor and marketing experts were advised to establish the face validity of the overall questionnaire.

\section{Data Analysis and Findings}

As suggested by (Hair et al., 1998), the value of Cronbach's alpha is higher than 0.919 which shows strong internal consistency among the items of the constructs. It further elaborates that the measured items effectively quantify a single construct for each variable which is tested (loyalty, quality, satisfaction, trust, switching cost and service price). Overall reliability $(\mathrm{n}=31)$ with by using Cronbach alpha is found .919 , with construct reliability as: service quality $.75(n=5)$, price $.627(n=5)$, customer satisfaction $.81(n=5)$, switching cost $.751(n=5)$, customer loyalty $.73(\mathrm{n}=6)$, and trust $.82(\mathrm{n}=5)$.

Data was collected from a total number of 92 respondents among which $60(65 \%)$ were male and $32(35 \%)$ were female respondents. The female junior management were $15 \%$ with middle management $14 \%$ and upper management $5 \%$ accordingly. The male respondents however were $12 \%$ (junior management), 32\% (middle managemtent) and $22 \%$ (upper managemtent). The highest number of respondents education wise were masters 49 in number and $53 \%$ of the total number of respondents followed by graduation $(37 \%)$, doctorate $(7 \%)$ and others $(3 \%)$ of the total respondents. However, highest were the middle management with $46 \%$ and 42 in number followed by $27 \%$ (each) from junior and upper management. The highest number of respondents were male with masters background (45\%) and the lowest were doctors and others (1\% each). Whereas the highest \%age of responednts in female were graduate $(18 \%)$ followed by masters $(9 \%)$, doctorate $(5 \%)$ and others $(2 \%)$. The highest number of respondents were from the IT industry with 42 respondents in number $(46 \%)$ followed by telecom (17\%), FMCG (15\%), textile (8\%), shipping (4\%), pharmaceutical (3\%, bank $(2 \%)$, media (2\%), automobile ) $1 \%$ ) and healthcare $(1 \%)$. Hence, responses include mostly from male, having master lvel education, having upper and middle tier level designations and belong to Telecom and FMCG sectors. 
Table 1

Descriptive analysis of constructs
\begin{tabular}{|lccccc|}
\hline & $\mathrm{N}$ & Minimum & Maximum & Mean & Std. Deviation \\
\hline Service Quality & 92 & 1.00 & 5.00 & 3.5652 & .76034 \\
Price & 92 & 2.00 & 4.60 & 3.6130 & .56709 \\
Customer Satisfaction & 92 & 1.00 & 5.00 & 3.6783 & .72139 \\
Switching & 92 & 1.00 & 5.00 & 3.2696 & .82085 \\
Customer Loyalty Rec & 92 & 1.00 & 5.00 & 3.5897 & .76098 \\
Customer Loyalty Pat & 92 & 2.00 & 5.00 & 3.6576 & .76291 \\
Trust & 92 & 1.00 & 5.00 & 3.3174 & .74607 \\
\hline
\end{tabular}

The table above shows few descriptive results for the research variables used in this study. The table shows minimum, maximum, standard deviation and mean for the research variables of trust, service quality, satisfaction, price and loyalty switching cost. The results are the summation of the variable from the five point likert (non-comparative) scale with ' 1 ' being 'strongly disagree' rating and ' 5 ' being 'strongly agree' rating from any respondent. The service quality's mean scores are 3.56 shows the research participants have slightly positive opinion of the service quality and are slightly away from mean ' 3 '. While, standard deviations are close to ' 0.7 ' showing on average deviation from their mean value or simply how deviated responses are on variables of stuffy from their mean value. The price mean scores are 3.61 which show that the research participants have slightly positive opinion of price and are slightly away from mean ' 3 '. While, standard deviations are close to ' 0.56 ' showing on average deviation from their mean value or simply how deviated responses are on variables of stuffy from their mean value.

The mean score of customer satisfaction is 3.67 which illustrates that the respondents have slightly positive assessment of customer satisfaction and are slightly away from mean ' 3 '. While standard deviations are close to ' 0.721 ' showing on average deviation from their mean value or simply how deviated responses are on variables of stuffy from their mean value. The mean scores of switching is 3.26 which explains that the participants have slightly positive assessment of switching cost and are slightly away from mean ' 3 '. While standard deviations are close to ' 0.821 ' showing an average deviation from their mean value or simply how deviated responses are on variables of stuffy from their mean value. The mean scores of loyalty are 3.58 and 3.65 explains the respondents have slightly positive assessment of switching cost and are slightly away from mean ' 3 '. While standard deviations are close to ' 0.76 ' showing an average deviation from their mean value or simply how deviated responses are on variables of stuffy from their mean value. The mean scores of trust is 3.31 which explains that the respondents have slightly positive evaluation of switching cost and are slightly away from mean ' 3 '. While standard deviations are close to '0.74' showing an average deviation from their mean value or simply how deviated responses are on variables of stuffy from their mean value.

Table 2

Correlation among the variables

\begin{tabular}{|c|c|c|c|c|c|c|c|}
\hline & $\begin{array}{l}\text { Service } \\
\text { Quality }\end{array}$ & Price & $\begin{array}{r}\text { Customer } \\
\text { Satisfaction }\end{array}$ & Switching & $\begin{array}{r}\text { Customer } \\
\text { Loyalty } \\
\text { (R) }\end{array}$ & $\begin{array}{c}\text { Customer } \\
\text { Loyalty } \\
\text { Patronage }\end{array}$ & Trust \\
\hline Service Quality & 1 & & & & & & \\
\hline Price & .201 & 1 & & & & & \\
\hline Customer Satisfaction & $.731 * *$ & $.338 * *$ & 1 & & & & \\
\hline Switching Cost & $.426^{* *}$ & -.115 & $.418^{* *}$ & 1 & & & \\
\hline Customer Loyalty ( R) & $.645^{* *}$ & .192 & $.766 * *$ & $.420 * *$ & 1 & & \\
\hline Customer Loyalty $(\mathrm{P})$ & $.565 * *$ & .203 & $.758 * *$ & $.384 * *$ & $.723 * *$ & 1 & \\
\hline Trust & $.499 * *$ & .153 & $.760 * *$ & $.482 * *$ & $.654 * *$ & $.763 * *$ & 1 \\
\hline
\end{tabular}

** Correlation is significant at the 0.01 level (2-tailed) 
The value of the coefficients of Pearson correlation test of association show that high correlation exists between the customer satisfaction and service quality. However, moderate correlation exists between service quality, customer loyalty (recommend \& patronage), switching cost and trust. The value of the coefficients of Pearson correlation test of association show that quite low correlation exists between price, service quality, customer satisfaction, switching cost, customer loyalty recommend and patronage. However, negative and almost negligible correlation exists between switching cost and price. The coefficients of Pearson correlation test of association show that strong correlation exists between customer satisfaction, service quality, customer loyalty (recommend and patronage) and trust. However, quite low correlation exists between customer satisfaction and price whereas moderate correlation exists between switching cost and customer satisfaction. The coefficients of Pearson correlation test of association show that strong correlation exists between switching cost, service quality, customer satisfaction, customer loyalty (recommend) and trust. However, negative and almost negligible correlation exists between switching cost and price whereas low correlation exists between switching cost and customer loyalty (patronage).

The coefficients of Pearson correlation test of association show that moderate correlation of customer loyalty (recommend) between service quality and trust exists. However, high correlation of customer loyalty (recommend) exists between customer loyalty (patronage) and customer satisfaction whereas almost negligible correlation exists between prices. There exists moderate relationship of customer loyalty (recommend) with switching cost. The coefficients of Pearson correlation test of association show that moderate correlation of customer loyalty (patronage) between service quality. However, high correlation of customer satisfaction, customer loyalty (recommend) and trust and weak correlation exists between prices and switching costs. The coefficients of Pearson correlation test of association show that trust has strong correlation between customer satisfaction and customer loyalty (patronage). However, moderate correlation of trust exists between switching cost, customer loyalty (recommend) and service quality. Also, almost negligible correlation exists between trust and prices. Thus, we may conclude that customer trust (patronage) relates positively to client loyalty.

Multiple regression analysis was performed, in order to examine the factors influencing customer loyalty in B2B market in Karachi. The below mentioned table illustrates that the regression coefficient is significant $(F(5,86)=46.751, p<0.01)$. The five independent variables (switching cost, customer satisfaction, price, trust and service quality) are correlated with the dependent variable, customer loyalty $(\mathrm{R}=.855)$. The $73.1 \%$ of customer loyalty variance $\left(\mathrm{R}^{2}=0.731\right)$ is explained by Switching cost, customer satisfaction, price, trust and service quality and $71.5 \%$ of customer loyalty variance of the population (Adjusted $\mathrm{R}^{2}=$ $0.715)$ 
Table 3

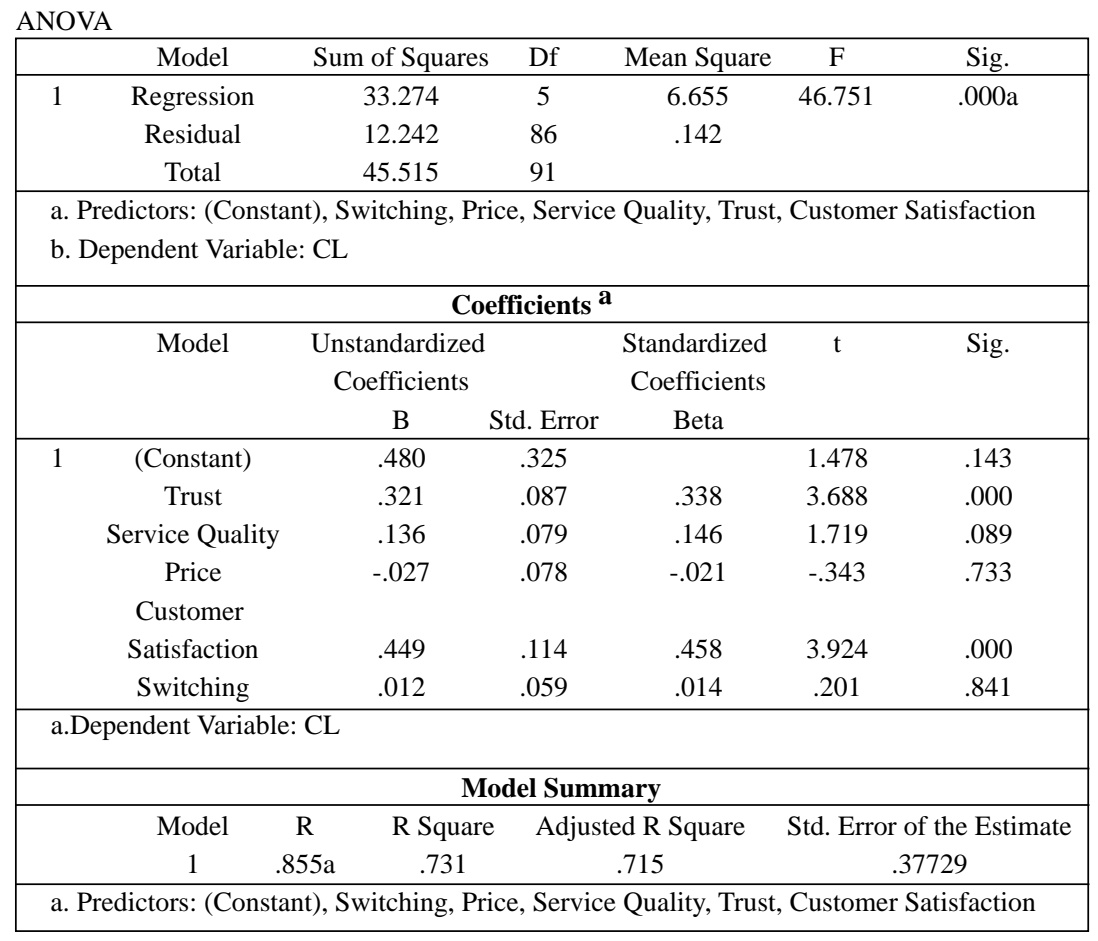

\section{Conclusion and Recommendations}

The findings of the study expand the previous study such as (Lam et al., 2009) and suggest that strong correlation exists between switching cost, service quality, customer satisfaction, customer loyalty (recommend) and trust. Service quality among other factors had the highest correlation with customer satisfaction. This shows that if service quality factors are enhanced, it will result in enhancing the customer satisfaction. Customer satisfaction however has a high correlation with customer loyalty and trust. The results in the previous studies (Lam et al., 2009) suggest that managers should enhance their customer loyalty and hence most of the hypotheses are supported. However, negative and almost negligible correlation exists between switching cost and price whereas low correlation exists between switching cost and customer loyalty (patronage). This suggests that in B2B environment, customers hardly switch due to pricing.

This study supports the previous study (Doney, Barry \& Abratt, 2007) which suggests that trust is displayed to have a positive impact on the relational outcomes, purchase shares and loyalty commitment. Among all the factors, trust had the highest correlation with switching costs. The findings of the study lead to the conclusion that customer loyalty is more dependent on trust, service quality rather than price. The demographic profile analysis revealed that the major data was collected from IT Industry and middle management males were the highest respondents. The research study shows that the five independent variables (customer satisfaction, customer value, switching costs and prices) are correlated with each other. This concludes

\begin{tabular}{|c|c|c|c|c|}
\hline JISR-MSSE & Volume 11 & Number 2 & July - December 2013 & 47 \\
\hline
\end{tabular}


that in order for the $\mathrm{b} 2 \mathrm{~b}$ marketing professionals to gain more insight over the customer loyalty and the factors that are influencing it. It further facilitates the marketers to organize the independent variables in such a manner that it increases the customer loyalty which benefits the business profitability as $73.1 \%$ variance is explained by these variables. Also, to enhance trust customer satisfaction should be improved.

The study concluded that there exists a highly significant relationship of customer value and satisfaction with customer retention, customer value and loyalty with customer retention and customer value, customer satisfaction, customer loyalty with customer retention. The previous study (Trasorras, 2009) concludes that there exists a highly significant relationship of customer value and satisfaction with customer retention, customer value and loyalty with customer retention and customer value, customer satisfaction, customer loyalty with customer retention. Our study expands the previous study and suggests that customer value does not directly affects the customer loyalty; there are certain mediating factors such as customer satisfaction and trust that play an important role hence these factors must be looked upon to gain more insight over the mentioned constructs.

The findings of the research suggest a few implications for the B2B organizations. First, the relationships explored provide a wider insight over the areas which must be explored to further enhance the business processes; and second, the myth of considering price as the major factor of switching costs has proved to be wrong. This implies the B2B professionals must consider the trust and service quality factors as the major influencers of customer satisfaction which leads to customer loyalty rather than factors such as price.

The research study has some restrictions that suggest prospects for further research. Primarily, the provided data is not specified to any one industry that symbolizes neither the characteristics of product or service industry. Though the research study explores the relation between the dependent and the independent variables but such wide focus may limit the generalization of our results. Secondly, due to the time and cost constraints, the sample size could not generalize the actual population of B2B market in Karachi (Pakistan); the sample was limited using a convenience and snowball sampling method. Finally, the relationship between customer's loyalty and satisfaction may get affected as the technological change rate in an industry couldn't be measured in this context. When the technological change is rapid, the customer loyalty and satisfaction are weak and vice versa. Further researches may incorporate this variable in their studies.

The relationship of trust with customer satisfaction, customer value and switching cost may be explored to sophistically evaluate these relationships. The relationship between customer satisfaction and customer loyalty may get affected as the technological change rate in an industry could not be measured in this context. Future researchers may incorporate this variable in their studies as when the technological change is rapid, the customer loyalty and satisfaction are weak and vice versa. 


\section{References}

Ahluwalia, R., Unnava, H. R., \& Burnkrant, R. E. (1999). Towards Understanding the Value of a Loyal Customer: An Information-processing Perspective. Cambridge: Marketing Science Institute.

Ajzen, I. \& Martin, F. (1980). Predicting and Understanding Consumer Behavior: AttitudeBehavior Correspondence in Understanding Attitudes and Predicting Social Behavior. New Jersey: Prentice Hall.

Bhote, K. R. (1996). Beyond Customer Satisfaction to Customer Loyalty: The Key to Greater Profitability. New York: American Management Association.

Boersma, M. F., Buckley, P. J., \& Ghauri, P. N. (2003). Trust in international joint venture relationship. Journal of Business Research, 56, 1031-1042.

Bolton, Ruth N. and James H. Drew (1991). A multi-stage model of customers' assessments of service quality and value, Journal of Consumer Research, 17 (4), 375-384.

Burnham, T. A., Frels, J. K., \& Mahajan, V. (2003). Consumer switching costs: A typology, antecedents, and consequences. Journal of the Academy of Marketing Science, 31(2), 109-126.

Callaghan, M., J. Mcphail \& O.H.M. Yau (1995), Dimensions of a relationship marketing orientation: an empirical exposition, Proceedings of the Seventh Biannual Word Marketing Congress, 7(2) 10-65.

Corbitt, B. J., Thanasankita, T., \& Yi, H. (2003). Trust and e-commerce: a study of consumer perceptions. Electronic Commerce Research \& Applications, 2(3), 203-215.

Cronin, J., Michael, K., Brady, K. \& Tomas, G. (2000). Assessing the effects of quality, value, and customer satisfaction on consumer behavioral intentions in service environments. Journal of Retailing, 76(2), 193-218.

Czepiel, J. (1990). Service encounters and service relationships: implication for research. Journal of Business Research, 20(1), 13-21.

Day, R. L. (1977). Extending the Concept of Consumer Satisfaction. Advances in Consumer Research, 4(1), 149-154.

Dick, A.S. \& Basu, K. (1994). Customer loyalty: toward an integrated conceptual framework. Journal of the Academy of Marketing Science, 22(2), 99-113.

Dwyer, F.R., Paul, H.S., Sejo, O. (1987). Developing buyer-seller relationships. Journal of Marketing, 11-27.

Fishbein, M., Ajzen, I. (1975). Belief, Attitude, Intention and Behavior: An introduction to Theory and Research, Addison-Wesley, Reading, MA.

\begin{tabular}{|c|c|c|}
\hline JISR-MSSE & Volume 11 & Number 2 \\
\hline
\end{tabular}


Fornell, Claes (1992), A national customer satisfaction barometer: the swedish experience, Journal of Marketing, 56, 6-21.

Gale, B.T., (1994). Managing Customer Value: Creating quality and service that customer can see, New York: Free Press.

Ganesan, S. (1994). Determinants of long-term orientation in buyer-seller relationships. Journal of Marketing, 1, 1-19.

Geyskens, I., Jan, B. E., Steenkamp, \& Kumar, N. (1999). A meta-analysis of satisfaction in marketing channel relationships. Journal of Marketing Research, 1, 223-238.

Hair, J.F., Anderson, R.E., Tatham, R.L., Black, W.C. (1998). Multivariate Data Analysis with Readings, Upper Saddle River, New Jersey: Prentice-Hall.

Heide, Jan B. \& Allen M. Weiss. (1995). Vendor consideration and switching behavior for buyers in high-technology markets, Journal of Marketing, 30-43.

Heskett, J.L., Thomas, O., Jones, G.W., Loveman, W.S, \& Leonard, A. (1994). Putting the service-profit chain to work. Harvard Business Review, 72 (2), 164-174.

Jones, M.A., Mothersbaugh, D.L., Beatty, S.E. (2002). Why customers stay: Measuring the underlying dimensions of services switching costs and managing their differential strategic outcomes. Journal of Business Research, 55, 441-450.

Kemp, R. \& Ghauri, P.N. (1998). The dynamics of joint venture relationship: a longitudinal perspective of two case studies, in A. Manrai \& L. Manray (Eds.) Research in Marketing, $14,123-150$.

Kotler, P. (1997). Marketing Management: Analysis, Planning, Implementation and Control, New Jersey: Prentice Hall.

Li, M. L., Green, R. D., Farazmand, F. A., \& Grodzki, E. (2012). Customer loyalty: influences on three types of retail stores' shoppers. International Journal of Management and Marketing Research, 5(1).

Liao, K. (2012). Service quality, and customer satisfaction: direct and indirect effects in a b2b customer loyalty framework. The Journal of Global Business Management, 8, $35-51$.

Lim, K.S., Razzaque, M.A. (1997). Brand loyalty and situational effects: an interactionist perspective. Journal of International Consumer Marketing, 9(4), 95-115.

Lutz, R. (1986). Quality is as quality doe: an attitudinal perspective on consumer quality judgments. In the Marketing Science Institute Trustees in proceedings in the international conference in Cambridge, MA. 
M, B. J., Doney, P., Barry, J., \& Abratt, R. (2007). Trust determinants and outcomes in global B2B services. European Journal of Marketing, 1096-1116.

Mittal, V., Ross, W.T. \& Baldasare, P.M. (1998), The asymmetric impact of negative and positive attribute-level performance on overall satisfaction and repurchase intentions, Journal of Marketing, 62, 33-47.

Mittal, V., Wagner, A., Kamakura., A. (2001). Satisfaction, repurchase intent, and repurchase behavior: investigating the moderating effect of customer characteristics. Journal of Marketing Research, 1, 131-142.

Moliner, M. A., Sánchez, J., Rodríguez, R. M., \& Callarisa, L. (2007). Relationship quality with a travel agency: The influence of the post purchase perceived value of a tourism package. Tourism and Hospitality Research, 194-2211.

Moorman, C., Deshpande, R. \& Zaltman, G. (1993). Factors affecting trust in market research relationships. Journal of Marketing, 57, 81-101.

Morgan, R. \& Hunt, D. (1994). The commitment-trust theory of relationship Marketing. Journal of Marketing, 58, 20-38.

Morgan, R., Crutchfield, T. \& Lacey, R. (2000). Patronage and loyalty strategies: understanding the behavioral and attitudinal outcomes of customer retention programs, in Thorsten Hennig-thurau \& Ursula Hansen (Eds.) Relationship Marketing.

Oliver, L. (1993). Cognitive, Affective, and Attribute Bases of the Satisfaction. Journal of Consumer Research, 20(3), 451-466.

Oliver, L. (1999). Whence customer loyalty. Journal of Marketing, 63, 33-44.

Paparoidamis, N. G., \& Caceres, R. C. (2007). Service quality, relationship satisfaction, trust, commitment and business to business loyalty. Service quality. European Journal of Marketing, 836-867.

Patricia, M. Doney \& Joseph, P.C. (1997). An examination of the nature of trust in buyerseller relationships. Journal of Marketing, 35-51.

Reichheld, F. (1993). Loyalty-based management. Harvard Business Review, 71(2), 64-73.

Rust, R., Zeithaml, V., \& Lemon, K. (2001). What drives customer equity. Marketing Management, 10(1), 20-25.

Ruth, N.B. (1998). A dynamic model of the duration of the customer's relationship with a continuous service provider: the role of satisfaction. Marketing Science, 17, 45-65.

Sirdeshmukh, D., Singh, J., Sabol, B., (2002). Consumer trust, value, and loyalty in relational exchanges. Journal of Marketing, 66(1), 15-37. 
Stephen L., Vargo A., Robert F. Lusch (2011), It's all B2B... and beyond: Toward a systems perspective of the market. Industrial Marketing Management, 40, 181-187.

Trasorras, R. J. (2009). Value, satisfaction, loyalty and retention in professional services. Marketing Intelligence \& Planning, 615-632.

Vakratsas, D., Ambler, T. (1999). How advertising works: what do we really know? Journal of Marketing, 63, 26-43.

Weiner, B. (1986). An Attribution Theory of Motivation and Emotion, Springer-Verlagm, New York.

Wong, A., \& Sohal, A. (2002). An Examination of the Relationship between Trust, Commitment and Relationship Quality. International Journal of Retail \& Distribution Management, 30(1), 34-50.

Woodruff, R.B. (1997), Customer value: the next source of competitive advantage. Journal of the Academy of Marketing Science, 25(2), 139-153.

Zeithaml, V. A. \& Bitner, M.J. (1996), Service Marketing, London: McGraw-Hill.

Zimmerman, A., \& Blythe, J. (2013). Business to Business Marketing Management: A Global Perspective. New York: South-Western College Pub. 


\section{Appendix}

\section{Items of questionnaire}

1. The company staff understands my business needs.

2. Timeliness of delivery of goods/services as promised.

3. Reliability in delivering products/services (accurately, on time, etc.)

4. $\quad$ Ease of doing business with the company.

5. Promptness in advising about any problems with my orders.

6. Costs incurred by the company (i.e., rates charged for actual services by the courier firms).

7. Delivery preparation costs incurred by the company (i.e., printing, packing, labeling, filling shipping forms, etc.)

8. Delay costs incurred by the company (i.e., costs related to fixing shipment delays, etc.)

9. Communication costs incurred by your company (i.e., costs of telephone, fax, etc., in dealing with the courier firms)

10. Costs incurred by your company in fixing problems with the firms' invoices and so on.

11. In general, my company is very satisfied with the services offered by the company.

12. Overall, my company is very satisfied with its relationship with the company.

13. Overall, the (other) company is a good company to do business with.

14. Overall, the (other) company treats my company very fairly.

15. Overall, the service of the (other) company comes up to my expectations.

16. It would cost my company a lot of money to switch from this company to another firm.

17. It would take my company a lot of effort to switch from one company to another firm.

18. It would take my company a lot of time to switch from this company to another firm.

19. If my company changed from this company to another company, some new technological problems would arise.

20. My company would feel uncertain if we have to choose a new firm.

21. I have said positive things about this company to other professional colleagues.

22. I have recommended this company to professional colleagues who seek my advice.

23. I have encouraged other companies to do business with this company.

24. My company considers this company as its first choice for the related products/services.

25. My Company will do more business with this company in the next few years.

26. Employee of company keeps to the promises, which he/she gives to our organization.

27. I believe that company considers our best interests.

28. I feel that I can always trust this company.

29. I believe that company will do everything correctly.

30. Employees of the company are honest.

31. I feel more confident when I purchase services from this company. 